\title{
Reference
}

Amartya Sen, (2006) What do we want from a theory of justice. The Journal of Philosophy CIII (5): $215-38$.

David Archard

Department of Philosophy, University of Lancaster,

Lancaster, UK

\section{The philosophy of Simone de Beauvoir: Ambiguity, conversion, resistance}

\author{
Penelope Deutscher \\ Cambridge University Press, Cambridge and New York, 2008, cloth, 199pp., \\ $£ 45, \$ 81$, ISBN: 978-0521885201
}

Contemporary Political Theory (2010) 9, 256-258. doi:10.1057/cpt.2009.22

In this important addition to the Cambridge Ideas in Context series, edited by Quentin Skinner and James Tully, Penelope Deutscher does indeed place the work of Simone de Beauvoir within its intellectual context. She provides an original and erudite treatment of Beauvoir's engagement with, and transformative 'conversions' of, the ideas of a wide range of her contemporaries (French and otherwise) as well as many prior thinkers. She also offers a reading of the many creative, and often incompatible, conversions that key concepts within Beauvoir's own body of work undergo, both within and among her texts.

Through reading Beauvoir as a thinker whose concepts not only shift but also often productively undermine, or 'autoresist,' themselves, Deutscher also speaks to contemporary debates about how, more generally, to make sense of incoherence and instability within a thinker's work. Rather than attempting to fix the most precise meaning of a concept, or to search for greater coherence in a body of work, Deutscher advocates mining fluid, unstable, or even contradictory, aspects. For these need not express intellectual failings on the part of a thinker (be it Beauvoir or another). Rather they are expressive of what Deutscher calls 'the multivalent ambiguity' of life, and they assist us in grasping 'our state of existing in various divided modes that cannot be reconciled' (p. 7).

For example, Beauvoir is often accused of logical inconsistency in The Second Sex since she asserts, on the one hand, that to be human is always to be free and, on the other, that women are not free. Instead, Deutscher argues,

256 (C) 2010 Macmillan Publishers Ltd. 1470-8914 Contemporary Political Theory Vol. 9, 2, 251-261 
Beauvoir shows 'that the subjugation of women is itself a paradox.' For women, qua human beings, may be defined 'in terms of an irrecusable freedom,' and so 'if they are nonetheless constrained, if there has been a diminishing of .... the very freedom of consciousness that, by a definition accepted by Beauvoir, is not diminishable, the paradox would belong to women's situation rather than to a deficiency in [Beauvoir's] understanding of freedom' (p. 9). Deutscher's affirmation of the value of Beauvoir's paradoxes and instabilities brings a tacit poststructuralist sensibility to her readings. Yet, one cannot say that this is a poststructuralist reading. For Deutscher's approach implies - provocatively perhaps - that there is, after all, very little rupture between the humanistic 'existentialism' of a thinker such as Beauvoir and the thought of 'antihumanist' French thinkers who, in the next generations, struggled so desperately to distance themselves from it.

For most Anglophone theorists, Beauvoir is above all the theorist of gender oppression. Her opus magnum, The Second Sex, (French, 1949) was hailed in the 1970 s as the Bible of 'second wave' feminism in Britain and the United States, and many of the key debates in feminist theory have since been fought out on the site of Beauvoir interpretation. But, gender was not Beauvoir's only concern and Deutscher's methodological reflections bear on her reading of Beauvoir as much wider theorist of oppression. In this account, 'alterity' becomes a key concept, that is, the making 'other' or the 'objectification' of subordinate or marginal social groups. The core chapters of Deutscher's book move kaleidoscopically among texts in which Beauvoir addresses forms of alterity that encompass race, age and (more occasionally) class, as well as gender.

In addition to her fine exegesis of The Second Sex, Deutscher explores in depth two works that have received much less scholarly attention: America Day by Day (French 1947) and The Coming of Age (French, 1970; Deutscher uses the US edition, but the British one is entitled Old Age). In the first, an account of her travels in the United States in 1947, Beauvoir reflects on the racism she discovered in the Deep South. She seeks to understand it by converting and combining arguably incompatible sociological insights from Gunnar Mydal's American Dilemma (1944) with elements of Marxism and with existential arguments adapted from Sartre's analysis of racism as a form of bad faith. In the later work, The Coming of Age, Beauvoir explores the lived experience of the aged as a form of alterity and marginalisation. This experience is, she argues, usually exacerbated by the condition of poverty that modern capitalism inflicts on those who have become unproductive.

In all cases, 'the problem' of alterity is foremost the problem of the oppressor group - of the bad faith of those who derive material and existential benefits from others by denying recognition to their freedom and subjectivity. But how oppressor and oppressed relate, how the oppressed variously assume their oppressed identities, how individuals become the bearers of multiple and often

(C) 2010 Macmillan Publishers Ltd. 1470-8914 Contemporary Political Theory Vol. 9, 2, 251-261 257 
conflictual subject and object statuses, and what paths there may - or may not be towards relations of greater reciprocity, are open questions. Deutscher argues that - although there are passages that point in other directions - in the 1940s, Beauvoir misguidedly treated the alterities of race and gender as distinct, largely occluding the specificities of black women's alterity in America Day by Day. It is only later, in The Coming of Age, that Beauvoir developed resources resources that Deutscher suggests could now be productively used to rework the earlier analyses of race and gender - that enable one to grasp the self as a multiplicity of often conflictual and unstable characteristics.

The last part of Deutscher's book, with its primary focus on The Coming of Age, is perhaps the richest. Here, Deutscher draws out a new conception of reciprocity that lies less in acknowledging the freedom we share with others than in our shared vulnerability. It is not only that old age comes to (almost) all of us. For the phenomenon of aging invites us more broadly to reconceptualize the subject and to consider other possible forms of reciprocity. We are all aging continuously and 'since age inhabits every subject' it invites us to focus on what we share in terms of 'exposure, vulnerability, fragility, transformation, embodied time' (p. 179). Herein lies not only an ethics but also a politics and a political economy. For, to ground reciprocity in the recognition of our shared vulnerability, we must cease to value individuals for their 'productivity,' or for their freedom or their autonomy. As its minimum precondition, as Beauvoir insists, this new kind of reciprocity will require a radical reconstruction of social and economic institutions.

\title{
Deliberative freedom: Deliberative democracy as critical theory
}

\author{
Christian F. Rostbøll \\ State University of New York Press, Albany, NY, 2008, 312 pp., hardcover, \\ \$80.00, ISBN 13: 978-0791474594
}

Contemporary Political Theory (2010) 9, 258-261. doi:10.1057/cpt.2009.24

Christian F. Rostbøll's book Deliberative Freedom: Deliberative Democracy as Critical Theory is unique for several reasons. First, it is the first book that deals

258 (C) 2010 Macmillan Publishers Ltd. 1470-8914 Contemporary Political Theory Vol. 9, 2, 251-261 